\title{
sciendo
}

\section{Is control still an important managerial function? An examination of structural and control process factors in strategic alliances}

\author{
Cosmin Florin LEHENE \\ Independent Researcher, Babes-Bolyai University - Alumni, Cluj-Napoca, Romania \\ lehenecosmin@ymail.com
}

\begin{abstract}
In this paper we aimed to find an answer to the question: is control still important for modern organization in order to favor achievement of superior performances? We have tried to find answer to this question through an empirical investigation in the field of strategic alliances. Thus, we have analyzed the relationship between alliance monitorization and control and various measures of alliance performances. Based on a statistical analysis of data provided by 46 best performers medium and large companies operating in Romania, we found that control is still important for superior performances, whether productivity (e.g. revenues growth) or innovation related performances (e.g. new product development). We used multiple multilinear regressions and found positive associations between alliance monitorization and control, structural control factors and productivity, respectively innovation related performances. Surprisingly, we found that control process factors are not associated with superior innovation performances and for productivity related performances there is only a low intensity association. In terms of explanatory potential of regression models, in five models out of six, the control factors significantly explained why some companies extracted higher value from their portfolio of strategic alliances, as compared to companies extracting more modest value. The various measures of alliance performances (revenues growth, competitive position, customer satisfaction, operations improvement, product improvement, new product development) were also separately investigated.
\end{abstract}

Keywords: strategic alliances, strategic control, alliance performances, productivity, innovation, MNC.

Please cite the article as follows: Lehene, C.F. (2021), "Is control still an important managerial function? An examination of structural and control process factors in strategic alliances", Management \& Marketing. Challenges for the Knowledge Society, Vol. 16, No. 4, pp. 316-333, DOI: 10.2478/mmcks-2021-0019.

\section{Introduction}

In the recent decades, strategic alliances have become ubiquitous phenomena in the business arena, capturing the attention of both management scholars and practitioners (Gulati, 1998). Collaboration is an effective way to access valuable resources, which are located outside organizations' boundaries (Albers et al., 2016; Gulati \& Singh, 1998; Kale et al., 2002). We refer to a strategic alliance to a voluntary collaboration between two or more organizations, which put in common some of their resources and competences in order to 
achieve competitive advantage and superior performances (Das \& Teng, 2000; Dyer \& Singh, 1998). The collaboration is based on an established agreement which can be contractual, formal and/or informal (Lehene, 2020).

Even though strategic alliances, as organizational forms, represent topics of modern research, their existence is as old as existence of organizations (Lehene, 2020). Along with the development of alliances field over time, many ideas regarding how the companies should manage and behave in strategic alliances have been developed. One important topic within this stream of research is alliance monitorization and control, which is the main subject in this paper. Many scholars studied the phenomena of monitorization and control in both management and strategic management fields.

In the management field there are currently some controversies regarding the monitorization and control of firms' activities, as a managerial function, and its importance for modern business context. For instance, Birkinshaw and Ridderstrale (2017) argue that modern organizations need to move towards new models for organizing their activities in order to be prepared for the future. The scholars argue that firms should move from traditional bureaucratic models towards knowledge-based oriented models (meritocracy models) or towards action-based oriented models (adhocracy models). In these new models for organizing activities the control managerial function takes on a different role than in traditional organizations (Birkinshaw \& Ridderstrale, 2017). For instance, in order to encourage proactivity among employees, to identify new ways to improve operations/products, managers need to be less restrictive in terms of controlling their behavior. Employees need more freedom of expression and more time to try new things (Hitt et al., 2007).

Moreover, there are now modern tools developed mainly within the business practice (e.g. AGILE) which supposedly will lead to flattening the organizational structure and perhaps will eliminate or reduce the need for control (Birkinshaw, 2010/2012). Also, along with the development of modern ambidextrous organizations the control function should be view differently because what drives innovation performances is totally different than what drives productivity related performances (Tushman \& O'Reilly, 1996; O'Reilly \& Tushman, 2013). As one can see, there are nowadays some controversies between traditional management and modern management paradigms regarding managerial control. Somehow, control is viewed as something managers are not willing to do (Birkinshaw, 2010/2012), that is taken for granted or perhaps is considered as not being important anymore for superior performances of the business.

Therefore, in this paper we are going to investigate if the control managerial function continues to be important for business practice. We try to investigate this aspect through an empirical investigation conducted in field of strategic alliances. Through the mean of a statistical examination of answers provided by 46 best performers medium and large companies operating in Romania we aim to investigate if the companies monitoring and controlling in a higher degree their strategic alliances obtain better performances as well.

On the other hand, in strategic management literature, most of the research regarding monitoring and controlling activities has been conducted from an alliance performances perspective. The topics of research regarding alliance performances differed in alliance studies in respect of the following aspects: how the performance was measured/modes of measurement (Christoffersen et al., 2014; Wahyuni et al., 2007), what 
criteria the companies used to measure alliance performances (Brătianu, 2002; Kale et al., 2002; Moeller, 2010; Popa, 2004), or what level of analysis was considered for measuring alliance performances (Christoffersen et al., 2014; Hoffmann, 2005).

Regarding the existent evidence, various studies examined the relationship between different modes of alliance control (e.g alliance contracts, formal vs. informal control) and alliance performances [Bouncken et al., 2016; Hoetker \& Mellewigt, 2009; Krishnan et al., 2015; Lehene \& Borza, 2017]. Most of evidence, however, was derived from studying the control phenomenon at dyadic/alliance level. Up to now, as far as we know, there is little evidence regarding the relationship between alliance monitorization and control and alliance performances at the portfolio level.

Narrowing down the discussion, there is little evidence regarding the specific control factors which might influence the achievement of superior alliance performances as well; more concretely, if structural control factors (alliance formation) or control process factors (alliance implementation) have an impact on alliance performances. Some evidence of structural and process factors and their influence on alliance performances is presented by Kauser and Shaw (2004), Wahyuni et al. (2007), Taylor (2005). Moreover, there is no evidence, as far as we know, regarding the effect/influence of different types of monitorization and control factors discussed above on different types of alliance performances (productivity, radical or incremental innovation).

Thus, given these gaps in existent alliance literature, in this paper, we try to find answers to the following questions: Companies and organizations, which monitor and control their alliances in a higher degree, achieve better performances as well? Between structural or control process factors, which factors might influence the achievement of superior alliance performances and for what types of alliance performances?

The paper might be valuable for both management scholars and practitioners. For academia, the paper contributes to the debate existent in the management field on whether control as a managerial function is still important. On the other hand, the paper contributes to the body of research existent in the strategic alliances field regarding the relationship between various control modes and alliance performances, bringing observational evidence at portfolio level. For business practice the paper might be important since it provides statistical evidence derived from studying best performers medium and large companies in Romania in respect to monitoring and controlling companies' strategic alliances and the relationship with productivity and innovation related performances.

The remainder of the paper continues as follows: we start with developing the theoretical framework, discussing the main results existent in the alliance literature regarding the topic in our paper. Then, we present the research methodology adopted in this paper. We continue with analyzing the data and discussing the main findings. The paper ends with conclusions.

\section{Literature review}

\section{Alliance Monitorization and Control}

There are two scientific domains in which aspects related to monitorization and control of activities are discussed. Firstly, within the management field, ideas and aspects related to monitorization, supervising, and controlling of activities, processes and/or people, are discussed by scholars in relation with control managerial function (Bartol \& Martin, 1994). On the other hand, the same or similar topics are discussed within the stage of evaluating 
strategies in the strategic management field. The concepts of monitorization and control overlap with that of evaluating strategies (David, 2007/2013), being interpreted perhaps such as two different views of the same phenomena. The evaluation is a concept much broader than the monitorization and control, however. In order to evaluate a strategy, managers will need to monitor and control the activities and processes developed in the organization, but they will also need to revise the bases of the initial planning (Borza, 2012). For instance, to revise the SWOT analysis. Outside the management field, scholars from other domains also discussed aspects and developed ideas regarding the monitorization and control of activities conducted in organizations. For instance, in organizational sociology (Vlăsceanu, 2003), organizational theory (Daft, 2010) or even in educational contexts (Albulescu \& Albulescu, 1999).

In general, there is a consensus among scholars that companies use two broad control strategies. The first one is called bureaucratic control strategy, formal control strategy or mechanistic control strategy. When using this control strategy, managers develop formal criteria, formal procedures, utilize the hierarchy in order to supervise and control the activities and supervise the people for which they are responsible. The second one is quite opposite. The organic control strategy, informal control strategy or social control strategy refer to an integrated set of informal activities aiming to supervise and monitor the activities conducted in organizations (Popa et al., 2013). A typical example encountered within the business practice is building an organizational culture aiming that all members adhere to the same social norms.

At the same time, the process of monitorization and control can be operational, tactical, or strategic (Popa et al., 2013). The operational control is utilized by the first-line managers, aims for the accomplishment of short-term goals and the control area is the team, project, or other first-line operational structure. The tactical control is medium-time oriented, is used typically by middle managers and aims for the monitorization and control of activities within organizational divisions or departments. Finally, the strategic control is used by executives/top managers and aims at the monitorization and control of the entire organization. The time span in the attention of strategic control is larger than for tactical or operational control (Nicolescu \& Popa, 2011).

In terms of monitorization and control in the context of strategic alliances we need to define at first the concept Alliance Monitorization and Control (AMC). For the purpose of this study, we have applied the concept of strategic control developed in the strategic management literature (Borza, 2012; Nicolescu \& Popa, 2011) to study strategic alliances. Thus, in the context of our paper, AMC is viewed as a managerial process/activity consisting in 1) revising the initial alliance goals, 2) measuring the alliance performances, 3) comparing the performances with the initial alliance goals and 4) adopting corrective actions if needed.

Alliance Monitorization and Control (AMC) differed in previous studies in respect of following theoretical perspectives: how the companies and organizations should monitor and control their activities (Băcanu, 2006; Borza, 2012; Brătianu, 2002; Popa, 2004), what criteria use the companies in order to check their alliance activity/mode of assessment, whether quantitative (e.g. accounting measures) [Christoffersen et al., 2014; Kale et al., 2002; Moeller, 2010], and/or qualitative (e.g. alliance stability) [Băcanu, 2006; Christoffersen et al., 2014; Popa, 2004], the domain of AMC activities being operationalized 
(e.g. financial/operational/overall), or level of analysis (e.g. firm vs. inter-organizational unit) [Christoffersen et al., 2014].

Particularizing to our subject of discussion AMC was studied at two levels of analysis/two areas of control: dyad/alliance level (Dyer \& Singh, 1998; Gulati, 1998; Hatfield et al., 1998; Taylor, 2005) and portfolio level - all the alliances and partnerships of a focal company (Collins \& Riley, 2013; de Leeuw et al., 2014; Heimericks et al., 2009; Hoffmann, 2005; 2007; Vapola et al., 2010).

Recently, researchers integrated the level of analysis with partner's point of view, regarding the performances extracted from alliances. This integration was called AMC perspectives (Lehene, 2020). Building on the extant literature in the field of strategic control, Lehene (2020) suggests that there are three AMC perspectives. Firstly, the companies and organizations need to monitor and control the inter-organizational activities within a single alliance (monitorization and control at dyadic level - alliance perspective). At this level, AMC consists in monitoring and controlling the activities in order to accomplish alliance's goals (Hatfield et al., 1998; Kale et al., 2002). Secondly, managers should assure that the specific alliance create/add value to the firm (dyad level of analysis, but partner's perspective). In this AMC perspective, the managers should assure that innovation and/or productivity related performances grew due to activities with alliances (Hoffmann, 2005; Kandemir et al., 2006; Moeller, 2010; Stolwijk et al., 2015). Finally, in the third perspective, AMC consists in monitoring and controlling all alliance activities of a focal company. The managers need to assure that all the alliances of a focal firm are aligned with the overall strategy, the other firm-level strategies (Dussauge \& Garrette, 1998; Hoffmann, 2005; Vapola et al., 2010) and that they contribute to the accomplishment of firm's general/fundamental goals (Holmberg \& Cummings, 2009).

\section{Structural versus control process factors and alliance performances}

Previous research investigated the relationship between various aspects of control and the performances the companies extracted from their strategic alliances. For instance, Krishnan et al. (2015) investigated the relationship between a control strategy based on using contracts, in comparison with one based on trust, and alliance performances, in the context of environmental uncertainty. Kauser \& Shaw (2004) found that control was critical for the successful management and performance of alliances formed by British companies. Other researchers studied the relationship between formal and relational control strategies and alliance performances (Bouncken et al., 2016; Hoetker \& Mellewigt, 2009; Lehene \& Borza, 2017). In studying formation vs operational control, Wahyuni et al. (2007) focused their attention on extent of control, focus of control/area of control and spillover of control. Despite these advancements, we have little evidence if and which specific control factors have an influence on achieving superior alliance performances.

Following the methodology used by other researchers in the alliances field (Taylor, 2005), we have separated the AMC construct in two separate theoretical constructs: Structural Control Factors (SCF) and Control Process Factors (CPF). SCF consist in establishing specific objectives and designing specific procedures for monitoring, supervising, and controlling the activities within the alliance, prior or at the moment the alliance formation. For example, naming a manager in charge of administering the relationship with a certain partner, or establishing certain KPIs for alliance control. On the other hand, PCF have to do with implementation of the specific SCF, once the alliance starts 
to be operationalized. Examples of process factors are the recommendations and feedback offered to alliance partners at the moment the relationship is not going on the supposed direction (Kauser \& Shaw, 2004; Heimericks et al., 2009; Hoffmann, 2005).

SCF are focal company centered, aim for establishing effective and efficient control mechanisms in order to prevent future dysfunctionalities, problems and prevent the opportunistic behavior in company's strategic alliances. On the other hand, CPF are mostly alliance-centered. They have to do with alliance implementation with activities and processes during alliance monitorization and control, in order to prevent the same problems as mentioned above (Kauser \& Shaw, 2004; Taylor, 2005; Wahyuni et al., 2007). In case the focus of attention is represented by all the alliances and partnerships of a focal company SCF and CPF shall be discussed for the portfolio of alliances - all alliances and partnerships of a focal company. Instead, if the control mechanism is focused on a single alliance, the focus of discussion is placed on SCF and CPF for the single alliance (Hoffmann, 2005).

In relation to the discussion above, the relationship between various factors and alliance performances is probably the most researched topic in the extant alliance literature (Lehene, 2018). Various methods and criteria were used by researchers in order to capture the performances the companies extracted from their strategic alliances and partnerships. A recent review of various methods and criteria utilized to measure alliance performances was conducted by Christoffersen et al. (2014).

In general terms, alliance performances can be discussed at three levels of analysis (Hoffmann, 2005). Firstly, most of evidence in relation with alliance performances was derived from studying strategic alliances at dyadic/alliance level (Lehene, 2018). Objective measures such as profitability, revenues growth, market share growth, ROI, and subjective measures such as managers satisfaction with the alliance, relational harmony, or satisfaction with the achievement of alliance goals were utilized by Bener \& Glaister (2010); Kauser \& Shaw (2004); Meier et al. (2015), Moeller (2010) or Sarkar et al. (2001). A different method for measuring alliance performances utilized at dyadic level is partners' accomplishment of alliance goals (Hatfield et al., 1998).

Secondly, at portfolio level, de Leeuw et al. (2014), Heimericks et al. (2009), Hoffmann (2005), Vapola et al. (2010) proposed different methods and criteria for measuring the performances achieved by companies with alliances. For instance, Heimericks et al. (2009) proposed four types of alliance portfolio management solutions: 1) functional and staffing solutions (e.g. alliance department); 2) tool-based solutions (e.g. codified best practices); 3) training solutions (e.g. in-house company courses): 4) thirdparty solutions (e.g. appeal to financial experts). At portfolio level, however, Hoffmann (2005) proposed that there are two separate domains in which separate performance measures for alliance portfolio should be designed and implemented: performance measures for alliance portfolio at business level and performance measures for alliance portfolio at corporate level. At the business level, the scholar proposed measures such as contribution of portfolio of alliances to achieving business unit goals, or the financial impact of alliances (e.g. profit growth due to the portfolio of strategic alliances).

Thirdly, at the corporate/firm level, Hoffmann (2005) proposed performance measures for alliance portfolio such as quality of relationships with core partners, reputational capital, or the development of alliance capability. 
Our view of alliance performances utilized in this paper is closed to that proposed by Hoffman (2005) and de Leeuw et al. (2014). Therefore, we refer to alliance performances to a theoretical construct aiming to capture the growth of company's performances related to productivity (e.g. revenues growth) or innovation (e.g. new product development) due to firm' portfolio of strategic alliances.

\section{Research problem and objectives}

The main research problem in this paper is to investigate if control, as a managerial function, is still important for the achievement of superior business performances. More specifically, if the companies which monitor and control their strategic alliances in a higher degree, in the modern business context, achieve superior performances as well. In the literature reviewed above and in our main research problem two key questions/objectives, which will be investigated in the empirical part, arise.

Firstly, despite the numerous advancements in the alliances' literature regarding the alliance monitorization and control, until the present day, there is little evidence at the portfolio level, whether the companies which monitor and control in a higher degree their strategic alliances obtain in fact better performances, as compared to the companies which monitor and control their alliances less. In other words, whether monitorization and control still contribute to the achievement of superior alliance performances in modern business context. On the other hand, as far as we know, there is no evidence regarding the relationship between alliance monitorization and control and different types of alliance performances, whether performances related to productivity or innovation.

Secondly, narrowing down our discussion, as far as we know, in the extant literature there is no evidence regarding the specific control factors - structural control factors as compared to control process factors - and their influence on the achievement of superior performances. In other words, which control factors contribute to achieving better alliance performances and in respect of what type of performances (productivity or innovation). Both research objectives will be investigated at portfolio level - all alliances and partnerships of a focal company.

\section{Research methodology}

\section{Research strategy}

The research strategy used in this paper is secondary data analysis, in the sense that we used some items from a questionnaire utilized in a previous study, but for other purpose, and combining the items in different theoretical constructs. For instance, the theoretical construct AMC was divided in two separate constructs: structural control factors and control process factors. Additional variables were also included in order to more accurately capture AMC as compared to the initial project. We have also eliminated some items from the previous project, since in this study we were not interested in what they measured. The main advantage of secondary data analysis is that it helps researchers to use the answers provided by respondents, no matter/independently of the goal of the present research (Chelcea, 2007).

The data analyzed was collected using a questionnaire which was administered through email, between October 2017 - March 2018. We have contacted the best performers 785 medium and large companies in Romania, depending to their revenues, out of which 46 companies decided to participate (leading to a participation rate of 5,85\%). 
Two sources were used in order to obtain the data regarding the best-performers companies operating in Romania: Top 500 Business Magazine (2016) and Top 1000 Piața Financiară (2017). The final sample consisted of 29 large companies (more than 250 employees) and 17 medium-size firms (between 50 and 249 employees). Two companies with less than 50 employees were included in the medium-size category. In these companies 34, respectively 31 employees were working. 30 executives (e.g. President, CEO, General Manager) participated in the study. In addition to the executive suite, the analysis consisted in the answers provided by 10 middle managers (e.g. marketing manager), 5 firstline managers/operations managers (e.g. team leader), and one marketing specialist.

\section{Variables}

The variables 'Alliance Monitorization and Control', 'Structural Control Factors', 'Control Process Factors', 'Productivity Related Performances', 'Innovation Related Performances' were measured using a 5-point Likert scale ranging from 1 to 5 with the following meaning " 1 = Strongly Disagree and $5=$ Strongly Agree". (Table 1.) The managers were asked to appreciate the extent to which the statement in the questionnaire fit the situation in their company, according to the scale mentioned above. We mention that in order to better understand the monitorization and control phenomena in organizations we have employed two modes of measurement for the dependent variables. Firstly, the Productivity Related Performances (PRP) and Innovation Related Performances (IRP) were measured as a single variable composed from summing the scores for three items related to each dimension. For PRP, we included the items Revenues Growth (RG), Competitive Position (CP) and Customers Satisfaction (CS). For IRP, we included the items Operations/Processes Improvement (OPER IMPROV), Product Improvement (PROD IMPROV), New Product Development (NPD).

Table 1. Variable Measurement

\begin{tabular}{lllll}
\hline Variable & $\begin{array}{l}\text { Number of } \\
\text { items }\end{array}$ & Measurement & $\begin{array}{l}\text { Cronbach } \\
\text { Alpha }\end{array}$ & References \\
\hline Alliance Monitorization and Control (AMC) & 9 & Likert 5-point & 0.803 & \\
Structural Control Factors (SCF) & 5 & Likert 5-point & 0.752 & \\
Control Process Factors (CPF) & 4 & Likert 5-point & 0.715 & \\
Productivity Related Performances (PRP) & 3 & Likert 5-point & 0.794 & Bener \& Glaister (2010); Kale et \\
Innovation Related Performances (IRP) & 3 & Likert 5-point & 0.797 & al. (2000); Kale et al. (2002); \\
Revenues Growth (RG) & 1 & Likert 5-point & - & Wallenburg \& Schaffler (2014) \\
Competitive Position (CP) & 1 & Likert 5-point & - & \\
Customers Satisfaction (CS) & 1 & Likert 5-point & - & \\
Operations Improvement (OPERIMPROV) & 1 & Likert 5-point & - & \\
Product Improvement (PRODIMPROV) & 1 & Likert 5-point & - & \\
New Product Development (NPD) & 1 & Likert 5-point & - & \\
\hline
\end{tabular}

Source: Authors' own elaboration based on references.

Secondly, we aimed to investigate in detail, 'at molecular level', the relationship between the proposed independent variables AMC, SCF and CPF and each one of the six items which were included in PRP or IRP dependent variables.

In terms of how we measured the alliance performances, we mention that we referred to all alliances of a focal firm - portfolio of alliances. Therefore, this is the unit of analysis. For PRP, managers had to appreciate whether the specific factor - revenues, competitive position, customers satisfaction - increased due to company's strategic alliances. For IRP, the managers had to appreciate the extent to which the company 
acquired new knowledge and/or abilities from partners which resulted in operations improvement, better products/product improvement, and new product development (NPD).

\section{Control variables}

Following other researchers (de Leeuw et al., 2014; Kale et al., 2002; Luvison \& de Man, 2015) we have controlled for the size of the firm (whether medium, large-size or very large size firm), internationality (whether Romanian or International company), and industry (whether younger or more mature industry). The variable Firm Size (FS) was measured using a nominal level scale with the following categories: 1) Medium-size firm (50-249 employees); 2) Large-size firm (250-1000 employees); 3) Very-large size firm (more than 1.000 employees). The variable Internationality (MNC) was measured by also using a nominal level scale with the following categories: 0 - if there was the case of a Romanian company; 1 - if there was the case of an International/Multinational company (MNC). Finally, the variable Industry (Ind) was measured again using a nominal level scale depending whether the company operates in a younger industry (e.g. IT) or within a more mature industry (e.g. car manufacturing).

\section{Data analysis}

We start the data analysis with presenting the descriptive statistics and correlation matrix of data in our study. In table 2 one can observe the results of our initial analysis. We would like to mention that the next correlations are zero order correlations. It means, no other variables were considered in studying the proposed relationships.

Table 2. Descriptive statistics and correlation matrix

\begin{tabular}{|c|c|c|c|c|c|c|c|c|c|c|c|c|c|c|c|}
\hline Variable & Min & Max & Mean & S.D. & AMC & SCF & CPF & PRP & IRP & RG & $\mathbf{C P}$ & CS & $\begin{array}{l}\text { OPER } \\
\text { IMPROV }\end{array}$ & $\begin{array}{l}\text { PROD } \\
\text { IMPROV }\end{array}$ & NPD \\
\hline AMC & 26 & 45 & 38.22 & 5.018 & 1.00 & $0.911^{* *}$ & $0.807^{* *}$ & $0.453^{* *}$ & $0.329 *$ & 0.399* & $0.386^{* *}$ & $0.420^{* *}$ & $0.452^{* *}$ & 0.202 & 0.246 \\
\hline SCF & 14 & 25 & 20.98 & 3.370 & & 1.00 & $0.492^{* *}$ & $0.409^{* *}$ & $0.369^{* *}$ & $0.310^{*}$ & $0.349^{* *}$ & $0.374^{* *}$ & $0.499^{* *}$ & 0.235 & $0.273^{*}$ \\
\hline CPF & 11 & 20 & 17.22 & 2.373 & & & 1.00 & $0.372^{* *}$ & 0.170 & $0.273^{*}$ & $0.316^{*}$ & $0.351^{* *}$ & 0.242 & 0.096 & 0.129 \\
\hline PRP & 6 & 15 & 12.50 & 2.137 & & & & 1.00 & $0.649^{* *}$ & $0.768^{* *}$ & $0.862^{* *}$ & $0.897^{* *}$ & $0.614^{* *}$ & $0.463^{* *}$ & $0.608^{* *}$ \\
\hline IRP & 6 & 15 & 12.65 & 2.532 & & & & & 1.00 & $0.655^{* *}$ & $0.438^{* *}$ & $0.556^{* *}$ & $0.828^{* *}$ & $0.867^{* *}$ & $0.863^{* *}$ \\
\hline RG & 2 & 5 & 4.20 & .833 & & & & & & 1.00 & $0.420^{* *}$ & $0.533^{* *}$ & $0.554^{* *}$ & $0.446^{* *}$ & $0.677^{* *}$ \\
\hline $\mathrm{CP}$ & 1 & 5 & 4.22 & .892 & & & & & & & 1.00 & $0.740^{* *}$ & $0.471^{* *}$ & $0.277^{*}$ & $0.406^{* *}$ \\
\hline CS & 2 & 5 & 4.09 & .812 & & & & & & & & 1.00 & $0.531^{* *}$ & $0.455^{* *}$ & $0.459^{* *}$ \\
\hline $\begin{array}{l}\text { OPER } \\
\text { IMPROV }\end{array}$ & 2 & 5 & 4.39 & .745 & & & & & & & & & 1.00 & $0.619^{* *}$ & $0.602^{* *}$ \\
\hline $\begin{array}{l}\text { PROD } \\
\text { IMPROV }\end{array}$ & 1 & 5 & 4.17 & 1.102 & & & & & & & & & & 1.00 & $0.568^{* *}$ \\
\hline NPD & 1 & 5 & 4.09 & 1.112 & & & & & & & & & & & 1.00 \\
\hline
\end{tabular}

Notes: ${ }^{* *} p<0.01 ;{ }^{*} p<0.05$ Sig. (1-tailed).

Source: Authors' own elaboration based on respondents' answers.

We can observe that there are positive associations between AMC and PRP $(\mathrm{r}=0.453 ; p<0.01)$ and IRP $(\mathrm{r}=0.329 ; p<0.05)$. At 'molecular level', there are still significant relationships between AMC and all items measuring PRP, but for IRP there is only a significant correlation between AMC and OPER IMPROV. We can also observe positive and significant associations between SCF and PRP ( $\mathrm{r}=0.409 ; p<0.01)$, respectively 
IRP ( $\mathrm{r}=0.369 ; p<0.01)$. Finally, we observe a significant association between CPF and PRP $(\mathrm{r}=0.372 ; p<0.01)$. At 'molecular level', we still observe significant relationships between SCF and all measures of PRP, while for innovation measures there are significant relationships only for OPER IMPROV and NPD.

Next, we used multiple regressions to evaluate the relationships between AMC but also SCF, respectively $\mathrm{CPF}$, and various dependent variables, eliminating the influence of tertiary variables, in different models of assessing performances extracted by companies from their portfolio of strategic alliances.

Table 3. Regression between AMC, SCF, CPF and dependent variables PRP and IRP

Dependent Variable: Ia - IIa; Ic - IIc; Ie - IIe: Productivity Related Performances (PRP); Ib - IIb; Id IId; If - IIf: Innovation Related Performances (IRP)

\begin{tabular}{|c|c|c|c|c|c|c|c|c|c|c|c|c|}
\hline & $\begin{array}{c}\text { Model } \\
\text { Ia }\end{array}$ & $\begin{array}{l}\text { Model } \\
\text { IIa }\end{array}$ & $\begin{array}{c}\text { Model } \\
\text { Ib }\end{array}$ & $\begin{array}{c}\text { Model } \\
\text { IIb }\end{array}$ & $\begin{array}{l}\text { Model } \\
\text { Ic }\end{array}$ & $\begin{array}{l}\text { Model } \\
\text { IIc }\end{array}$ & $\begin{array}{l}\text { Model } \\
\text { I d }\end{array}$ & $\begin{array}{l}\text { Model } \\
\text { IId }\end{array}$ & $\begin{array}{c}\text { Model } \\
\text { Ie }\end{array}$ & $\begin{array}{c}\text { Model } \\
\text { IIe }\end{array}$ & $\begin{array}{l}\text { Model } \\
\text { If }\end{array}$ & $\begin{array}{l}\text { Model } \\
\text { IIf }\end{array}$ \\
\hline Firm Size (FS) & -0.192 & -0.275 & -0.264 & $-0.332^{*}$ & -0.191 & -0.271 & -0.265 & $-0.347^{*}$ & -0.192 & -0.233 & -0.264 & -0.284 \\
\hline $\begin{array}{l}\text { Internationality } \\
\text { (MNC) }\end{array}$ & -0.076 & -0.001 & 0.060 & 0.122 & -0.076 & 0.041 & 0.043 & 0.162 & -0.076 & -0.094 & 0.060 & 0.052 \\
\hline Industry (Ind.) & -0.277 & -0.164 & -0.174 & -0.082 & -0.277 & -0.172 & -0.189 & -0.081 & -0.277 & -0.217 & -0.174 & -0.146 \\
\hline $\begin{array}{l}\text { Alliance } \\
\text { Monitorization and } \\
\text { Control (AMC) }\end{array}$ & - & $0.473^{* *}$ & - & $0.386^{*}$ & & & & & & & & \\
\hline $\begin{array}{l}\text { Structural Control } \\
\text { Factors (SCF) }\end{array}$ & & & & & - & $0.435^{* *}$ & - & $0.446^{* *}$ & & & & \\
\hline $\begin{array}{l}\text { Control Process } \\
\text { Factors (CPF) }\end{array}$ & & & & & & & & & - & $0.375^{*}$ & - & 0.180 \\
\hline $\mathrm{R}^{2}$ & 0.082 & 0.284 & 0.084 & 0.219 & 0.083 & 0.250 & 0.086 & 0.261 & 0.082 & 0.215 & 0.084 & 0.115 \\
\hline F-value & 1.188 & $3.870^{*}$ & 1.225 & $2.738^{*}$ & 1.237 & $3.325^{*}$ & 1.285 & $3.539 *$ & 1.188 & $2.664^{*}$ & 1.225 & 1.263 \\
\hline
\end{tabular}

Notes: Values for coefficients are standardized (Beta). ${ }^{* *} p<0.01 ;{ }^{*} p<0.05$.

Source: Authors' own elaboration based on respondents' answers.

In Table 3, for the Model Ia, we can see that none of the control variables have a significant effect on Productivity Related Performances (PRP). Moreover, less than 1\% $(0,8 \%)$ from the dispersion of PRP can be explained by control variables. This percentage grows to $28.4 \%$ in the case of all variables in Model IIa. More concrete, at least $28.4 \%$ from the dispersion of PRP can be explained by the four variables considered in this model. The difference between $\mathrm{R}$-square values is $\Delta \mathrm{R}^{2}=20.2 \%$, denoting an increase in the explanatory power of Model IIa with $20.2 \%$ as compared to the control model (Model Ia). For the Model Ia, we observe that $\mathrm{F}(3,40)=1.188$ and is not statistically significant for the control variables $(p>.05)$. But, for the Model IIa, which contains our variable of interest (AMC), we obtained $\beta=0.473, \mathrm{~F}(4,39)=3.870, p<.05$, denoting a highly positive and significant effect of AMC on PRP. Given this fact, we observe that the variable AMC explains in a statistically significant manner the variation of companies related to their PRP, given the elimination of influence of control variables. In other words, if we were to explain the differences in Productivity Related Performances of the companies in our study - why some best performers companies extract higher productivity-related value from their strategic alliances, as compared to other best performers companies - we can say that in a greater detail $(20,2 \%)$ the dispersion/variation is due to differences in their AMC. Companies 
monitoring and controlling their strategic alliances in a higher degree also extract higher value from their portfolio of strategic alliances.

The same analysis was conducted for all the regression models in our study. Out of editorial constrains, we are not going to report this detailed analysis for all the regression models. The main results, however, will be reported in patterns next, in the discussion section.

Table 4. Regression analysis between AMC and each dependent variable

Dependent Variable: Ia - IIa: Revenues Growth (RG); Ib - IIb: Competitive Position (CP): Ic - IIc: Customers Satisfaction (CS); Id - IId: Operations/Processes Improvement (OPER IMPROV); Ie - IIe: Product Improvement (PROD IMPROV); If - IIf: New Product Development (NPD)

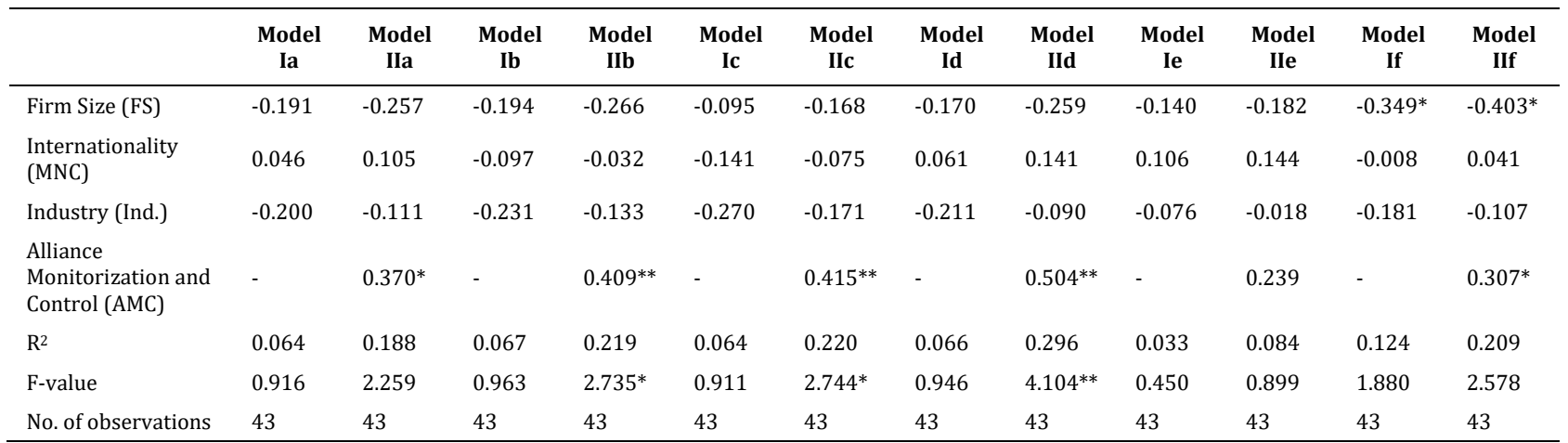

Notes: Values for coefficients are standardized (Beta). ${ }^{* *} p<0.01 ;^{*} p<0.05$.

Source: authors' own elaboration based on respondents' answers.

Table 5. Regression analysis between SCF and each dependent variable

Dependent Variable: Ia - IIa: Revenues Growth (RG); Ib - IIb: Competitive Position (CP): Ic - IIc: Customers Satisfaction (CS); Id - IId: Operations/Processes Improvement (OPER IMPROV); Ie - IIe: Product Improvement (PROD IMPROV); If - IIf: New Product Development (NPD)

\begin{tabular}{|c|c|c|c|c|c|c|c|c|c|c|c|c|}
\hline & $\begin{array}{c}\text { Model } \\
\text { Ia }\end{array}$ & $\begin{array}{c}\text { Model } \\
\text { IIa }\end{array}$ & $\begin{array}{c}\text { Model } \\
\text { Ib }\end{array}$ & $\begin{array}{c}\text { Model } \\
\text { IIb }\end{array}$ & $\begin{array}{c}\text { Model } \\
\text { Ic }\end{array}$ & $\begin{array}{c}\text { Model } \\
\text { IIc }\end{array}$ & $\begin{array}{c}\text { Model } \\
\text { Id }\end{array}$ & $\begin{array}{l}\text { Model } \\
\text { IId }\end{array}$ & $\begin{array}{c}\text { Model } \\
\text { Ie }\end{array}$ & $\begin{array}{l}\text { Model } \\
\text { IIe }\end{array}$ & $\begin{array}{c}\text { Model } \\
\text { If }\end{array}$ & $\begin{array}{l}\text { Model } \\
\text { IIf }\end{array}$ \\
\hline Firm Size (FS) & -0.192 & -0.257 & -0.194 & -0.262 & -0.094 & -0.161 & -0.171 & $-0.277^{*}$ & -0.143 & -0.196 & -0.348 & -0.412 \\
\hline Industry (Ind.) & -0.204 & -0.118 & -0.231 & -0.141 & -0.266 & -0.177 & -0.222 & -0.083 & -0.104 & -0.035 & -0.179 & -0.095 \\
\hline $\begin{array}{l}\text { Structural } \\
\text { Control Factors } \\
\text { (SCF) }\end{array}$ & - & $0.357^{*}$ & - & $0.373^{*}$ & - & $0.367^{*}$ & - & $0.577^{* *}$ & - & 0.287 & - & $0.348^{*}$ \\
\hline $\mathrm{R}^{2}$ & 0.065 & 0.178 & 0.069 & 0.191 & 0.063 & 0.182 & 0.068 & 0.361 & 0.031 & 0.104 & 0.124 & 0.230 \\
\hline F-value & 0.951 & 2.160 & 1.008 & 2.367 & 0.924 & 2.227 & 0.996 & $5.657^{* *}$ & 0.439 & 1.155 & 1.926 & $2.994^{* *}$ \\
\hline $\begin{array}{l}\text { No. of } \\
\text { observations }\end{array}$ & 44 & 44 & 44 & 44 & 44 & 44 & 44 & 44 & 44 & 44 & 44 & 44 \\
\hline
\end{tabular}

Notes: Values for coefficients are standardized (Beta). ${ }^{* *} p<0.01{ }^{*} p<0.05$.

Source: Authors' own elaboration based on respondents' answers. 
Table 6. Regression analysis between CPF and each dependent variable

Dependent Variable: Ia - IIa: Revenues Growth (RG); Ib - IIb: Competitive Position (CP): Ic - IIc: Customers Satisfaction (CS); Id - IId: Operations/Processes Improvement (OPER IMPROV); Ie - IIe: Product Improvement (PROD IMPROV); If - IIf: New Product Development (NPD)

\begin{tabular}{|c|c|c|c|c|c|c|c|c|c|c|c|c|}
\hline & $\begin{array}{c}\text { Model } \\
\text { Ia }\end{array}$ & $\begin{array}{l}\text { Model } \\
\text { IIa }\end{array}$ & $\begin{array}{c}\text { Model } \\
\text { Ib }\end{array}$ & $\begin{array}{c}\text { Model } \\
\text { IIb }\end{array}$ & $\begin{array}{l}\text { Model } \\
\text { Ic }\end{array}$ & $\begin{array}{l}\text { Model } \\
\text { IIc }\end{array}$ & $\begin{array}{l}\text { Model } \\
\text { Id }\end{array}$ & $\begin{array}{l}\text { Model } \\
\text { IId }\end{array}$ & $\begin{array}{c}\text { Model } \\
\text { Ie }\end{array}$ & $\begin{array}{l}\text { Model } \\
\text { IIe }\end{array}$ & $\begin{array}{l}\text { Model } \\
\text { If }\end{array}$ & $\begin{array}{l}\text { Model } \\
\text { IIf }\end{array}$ \\
\hline Firm Size (FS) & -0.191 & -0.221 & -0.194 & -0.231 & -0.095 & -0.134 & -0.170 & -0.197 & -0.140 & -0.150 & $-0.349 *$ & $-0.366^{*}$ \\
\hline $\begin{array}{l}\text { Internationality } \\
\text { (MNC) }\end{array}$ & 0.046 & 0.034 & -0.097 & -0.112 & -0.141 & -0.157 & 0.061 & 0.050 & 0.106 & 0.102 & -0.008 & -0.015 \\
\hline Industry (Ind.) & -0.200 & -0.157 & -0.231 & -0.178 & -0.270 & -0.215 & -0.211 & -0.172 & -0.076 & -0.061 & -0.181 & -0.156 \\
\hline $\begin{array}{l}\text { Control Process } \\
\text { Factors (CPF) }\end{array}$ & - & 0.270 & - & $0.329 *$ & - & $0.349 *$ & - & 0.244 & - & 0.092 & - & 0.156 \\
\hline $\mathrm{R}^{2}$ & 0.064 & 0.133 & 0.067 & 0.170 & 0.064 & 0.179 & 0.066 & 0.123 & 0.033 & 0.041 & 0.124 & 0.147 \\
\hline F-value & 0.916 & 1.495 & 0.963 & 1.990 & 0.911 & 2.122 & 0.946 & 1.361 & 0.450 & 0.413 & 1.880 & 1.675 \\
\hline No. of observations & 43 & 43 & 43 & 43 & 43 & 43 & 43 & 43 & 43 & 43 & 43 & 43 \\
\hline
\end{tabular}

Notes: Values for coefficients are standardized (Beta). ${ }^{* *} p<0.01{ }^{*} p<0.05$.

Source: Authors' own elaboration based on respondents' answers.

\section{Discussion and managerial implications Main patterns}

Given the analysis conducted above, in the next paragraphs we are going to discuss the main results in patterns, organized according to key research questions. More specifically, in the main patterns section we will discuss the findings in relation with the key questions/research objectives, while in the specific patterns section we will present the findings related to the key questions/research objectives but in detail, at 'molecular level'.

Firstly, regarding the first key question/research objective, we can observe a highly positive and significant effect of AMC on PRP $(\beta=0.473 ; p<0.01)$ and a medium intensity effect of AMC on IRP ( $\beta=0.386 ; p<0.05)$. This means that companies and organizations monitoring and controlling in a higher degree their alliances obtain better performances due to their portfolio of alliances, for both, productivity and innovation related performances.

These results somehow contradict/challenge - or at least contribute to a better clarification - the current view existent in the management field that living in 'the AGILE age', with flattening organizational structures, and organizations giving an increase role to innovation, controlling managerial function is somehow not important anymore. These results obtained from studying strategic alliances of best performers medium and large companies indicate that controlling, as a managerial function, continues to be important for the achievement of superior performances. Best performers companies in Romania monitor and control their strategic alliances in a higher degree and this fact results in extracting higher value from their strategic alliances. The fact that controlling activities and/or processes is not the most appreciated managerial activity yes, or that is required a different control strategy to be designed and implemented yes, but as our data suggest the companies which obtain better performances monitor and control in a higher degree their alliances, in comparison with companies obtaining lower performances. Thus, 
monitorization and control continues to be an indispensable and very important managerial activity/task.

For the second key question/research objective, we can observe a highly positive and significant effect of SCF on PRP $(\beta=0.435 ; p<0.01)$ and IRP $(\beta=0.446 ; p<0.01)$. Instead, for CPF we obtained a medium intensity and positive effect of CPF on PRP $(\beta=0.375 ; p<0.05)$ and no significant effect of CPF on IRP $(\beta=0.180 ; p>0.01)$. For both types of alliance performances, we can observe that SCF (initial/alliance formation factors) have a more pronounced and significative effect on alliance performances, as compared to CPF (alliance implementation factors). These results suggest that companies which extract higher value from their strategic alliances are preoccupied with establishing formal and concrete control indicators/procedures for monitoring their alliance activity at the beginning of the relationship and these structural factors have a significant effect on achieving better performances due to firm's strategic alliances.

In terms of explanatory potential of regression models, $\mathrm{AMC}\left(\Delta \mathrm{R}^{2}=20.2 \% ; p<0.05\right)$, SCF $\left(\Delta \mathrm{R}^{2}=16.7 \% ; p<0.05\right)$ and CPF $\left(\Delta \mathrm{R}^{2}=13.3 \% ; p<0.05\right)$ explained significantly the variation of companies in terms of their performances related to productivity. This means that if we were to explain why best performers companies in Romania obtain better performances related to productivity, as compared to other best performers companies with more modest PRP, to a large extent, the differences are due the fact that those companies which obtain better performances monitor and control their strategic alliances in a higher degree. The same rationale can be applied for innovation related performances. The AMC $\left(\Delta \mathrm{R}^{2}=13.5 \% ; p<0.05\right)$ and $\operatorname{SCF}\left(\Delta \mathrm{R}^{2}=17.5 \% ; p<0.05\right)$ explained significantly why some best performers companies obtain better innovation related performances due to their alliances.

\section{Specific patterns}

Next, we regressed AMC on each item related to PRP and IRP. We found a mix picture of effects of AMC on different alliance performances measures. We observe a low to medium, positive, but significative effect of AMC on RG $(\beta=0.370 ; p<0.05)$ and NPD $(\beta=0.307$; $p<0.05)$, a moderate to high positive effect of AMC on CP $(\beta=0.409 ; p<0.01)$ and CS $(\beta=0.415 ; p<0.01)$ and a highly positive and significant effect of AMC on OPER IMPROV $(\beta=0.504 ; p<0.01)$.

Regressing SCF on each item related to alliance performances, we observe two 'extreme' patterns. One in which we observe a significant and low to moderate intensity effect of SCF on RG ( $\beta=0.357 ; p<0.05)$, CP $(\beta=0.373 ; p<0.05)$, CS $(\beta=0.367 ; p<0.05)$, NPD $(\beta=0.348 ; p<0.05)$ and other in which we observed a highly positive and significative effect of SCF on OPER IMPROV $(\beta=0.577 ; p<0.01)$.

In terms of implementation factors, we regressed CPF on each item measuring alliance performances and we have identified a significant effect of CPF only on $\operatorname{CP}(\beta=0.329 ; p<0.05)$ and $\operatorname{CS}(\beta=0.349 ; p<0.05)$.

In terms of explanatory potential of regression models, only for three models AMC significantly explained the variation of companies in terms of alliance performances. We observe that AMC explained very significantly the variation of companies depending on OPER IMPROV $\left(\Delta \mathrm{R}^{2}=23 \%\right.$; $\left.p<0.01\right)$. In other words, in case of companies which better improved their operations/processes due to the knowledge or abilities acquired from their alliance partners to a large extent, the improvement is due the fact that these companies 
monitor and control their portfolio of alliances in a higher degree. AMC also significantly explained the variation of companies depending on competitive position $\operatorname{CS}\left(\Delta \mathrm{R}^{2}=15.2 \%\right.$; $p<0.05)$ and customer satisfaction $\operatorname{CS}\left(\Delta \mathrm{R}^{2}=15.6 \%\right.$; $\left.p<0.05\right)$. Companies monitoring and controlling in a higher degree their strategic alliances will have more partnerships which will result in an improvement in terms of competitive position and customers satisfaction.

Structural control factors significantly explained the variation of companies only depending on OPER IMPROV $\left(\Delta \mathrm{R}^{2}=29.3 \% ; p<0.01\right)$ and NPD $\left(\Delta \mathrm{R}^{2}=10.6 \% ; p<0.01\right)$. To a large extent, in case of companies which improved their operations/processes or developed a new product due the knowledge or abilities acquired from their alliance partners, the improvement or development of the new product is due the fact that these companies monitored and controlled their strategic alliances in a higher degree. The companies with more modest scores for innovation related performances were less preoccupied to establish structural control factors.

Finally, control process factors failed to significantly explain the variation of companies depending their alliance performances.

\section{Implications for management}

The findings from our research might have implications for the management practice. Firstly, managers should be aware that control is still important for achieving superior business performances, whether productivity or innovation. Whether companies aim to improve their revenues, achieve a better competitive position in the market or simply see an improve in customer satisfaction due to their strategic relationships/alliances, they need to increase their attention devoted to monitoring and controlling their strategic alliances.

The same is true for achieving knowledge and competences from alliance partners, which might have the potential to result in operations and/or products improvement, or even the development of a new product due the knowledge and/or competences acquired from company's partners. Nevertheless, if within one company there is no interest to monitor the alliance partners right from the start, the learning and acquisition of knowledge from partners will be minimized (no matter how important is that knowledge). Some knowledge and competences are tacit, embedded in partners' organizational routines and hard to observe without a proper, formal, and systematic monitorization.

Secondly, companies might be aware of the importance of establishing formal procedures and criteria at the beginning of the relationship in order to monitor and control the relationship among the implementation phase. For example, companies need to name a manager in charge of monitoring all the alliances of a company/business unit and/or name some alliance managers for important strategic alliances. At the same time, specific procedures for monitoring alliance evolution might be established. For example, developing a certain protocol for specific situations requiring termination, prolongation, or changes in alliance's structure.

\section{Limitations and future avenues for research}

Of course, there are limitations in our study. For instance, the control process factors considered in our analysis are perhaps not the items with the best construct validity. There are other control process factors important such as developing trust, building emotional bonds between employees working in the alliance, motivating employees etc. We have not considered these factors in our study. Likewise, since our results were obtained from data 
provided by a sample of best performers companies, it is not sure whether we will obtain the same results in the case we study average or below average companies. The same might be true for SMEs or companies operating outside Eastern Europe. But despite these limitations, this paper brings valuable evidence that in Romania best performers companies use control strategies in a higher degree and the higher use of control is positively associated with extracting superior performances from companies' portfolio of strategic alliances.

These limitations, however, might favor the development of new studies in this area of inquiry. As mentioned above, new research might investigate the relationship between control process factors and alliance performances through considering new items which are also associated with alliance implementation phase (e.g trust). In the same line of thinking, evidence obtained after studying the relationship between both dimensions of alliance control and alliance performances in the case of SMEs and entrepreneurial firms would be valuable in order to increase our understanding of monitorization and control phenomenon in organizations.

Likewise, in our paper we have derived our conclusions after considering, to a large extent, executives' and middle management perspective. It would be interesting to investigate partners' perspective in terms of alliance monitorization and control. In addition, in-depth and detailed case studies in which the researchers are immersed effectively in the company, observe and participate in alliance activities, also might bring valuable evidence regarding the process of monitorization and control implemented by companies. Differences between medium and large companies operating in Romania, as compared to medium and large companies operating in other parts of the world, regarding the effect of alliance monitorization and control on alliance performances might also be considered.

\section{Conclusions}

In this paper, we have analyzed the relationship between alliance monitorization and control and performances the companies extracted from their portfolio of strategic alliances. Given our first research key question, we found that control, as a managerial function, is still important for the achievement of business superior performances, whether performances related to productivity or innovation. Best performers, MNC and national companies operating in Romania, monitor and control their activities to a higher degree and the higher degree of control is positively associated with better performances, for both types of performances, productivity and innovation.

Regarding the second research key question, the structural factors are more important for extracting superior alliance performances, as compared to control process factors. Best performers companies establish clear goals for alliances and use clear procedures to manage them and in turn, these structural control factors being associated with extracting higher value from their portfolio of strategic alliances. This finding is true for both types of performances, whether we analyzed productivity or innovation related performances. On the other hand, surprisingly, process factors are not associated with superior innovation performances and for productivity there is only a relatively low intensity association between control process factors and related performances.

In conclusion, managers should be aware that control is still an indispensable managerial activity which should not be omitted or taken for granted, as it is part of a 
manager's work. As a managerial function, control is necessarily for the achievement of organizational goals and is even correlated with superior performances. Managers monitoring and controlling organizational activities in a higher degree are more likely to accomplish organizational goals. The fact that a different type of control strategy is required to be designed and implemented in order to deal with modern challenges (e.g. flattening organizational structures, ambidextrous strategic directions etc.) is another discussion, which can be debated in a new paper.

\section{References}

Albers, S., Wohlgezogen, F., \& Zajac, E. (2016). Strategic Alliance Structures: An Organization Design Perspective. Journal of Management, 42(3), 582-614.

Albulescu, I., \& Albulescu, M. (1999). Didactica disciplinelor socio-umane. Cluj-Napoca: Napoca Star.

Bartol, K. M., \& Martin, D.C. (1994). Management. 2nd ed. McGraw-Hill.

Băcanu, B. (2006). Management strategic. Brașov: Editura Infomarket.

Bener, M., \& Glaister, K. (2010). Determinants of performance in international joint ventures. Journal of Strategy and Management, 3(3), 188-214.

Birkinshaw. J [2010] (2012). Reinventing Management: Smarter Choices for Getting Work Done. West Sussex: John Wiley \& Sons.

Birkinshaw, J., \& Ridderstrale, J. (2017). Fast/Forward: make your company fit for the future. California: Stanford University Press.

Borza, A. (2012). Management Strategic. Cluj-Napoca: Editura Risoprint.

Bouncken, R., Clauß,T., \& Fredrich, V. (2016). Product innovation through coopetition in alliances: Singular or plural governance? Industrial Marketing Management, 53, 77-90.

Brătianu, C. (2002). Management strategic. Craiova: Editura Universitaria

Business Magazin (2016, October 24). Acestea sunt cele mai mari companii din România. Pe ce loc se află prima companie românească. Business Magazin. Retrieved from: https://www.businessmagazin.ro/actualitate/acestea-sunt-cele-mai-mari-companiidin-romania-pe-ce-loc-se-afla-prima-companie-romaneasca-15849928.

Chelcea, S. (2007). Metodologia cercetării sociologice. Metode cantitative și calitative. București: Editura Economică.

Christoffersen, J., Plenborg, T., \& Robson, M. (2014). Measures of strategic alliance performance, classified, and assessed, International Business Review, 23, 479-489.

Collins, J. \& Riley, J. (2013). Alliance Portfolio Diversity and Firm Performance: Examining Moderators. Journal of Business and Management, 19(2), 35-50.

Daft, R. (2010). Understanding the theory and design of organizations. Mason, OH: SouthWestern Cengage Learning.

Das, T., \& Teng, B-S. (2000). A Resource-Based Theory of Strategic Alliances. Journal of Management, 26(1), 31-61.

David, F. [2007] (2013). Strategic Management. Concepts and Cases. NJ: Pearson/Prentice Hall.

de Leeuw, T., Lokshin, B., \& Duysters, G. (2014). Returns to alliance portfolio diversity: The relative effects of partner diversity on firm' $s$ innovative performance and productivity. Journal of Business Research, 67, 1839-1849.

Dussauge, P., \& Garrette, B. (1998). Anticipating the Evolution and Outcomes of Strategic Alliances Between Rival Firms. International Studies of Management \& Organization, 27(4), 104-126.

Dyer, J., \& Singh, H. (1998). The Relational View: Cooperative Strategy and Sources of Interorganizational Competitive Advantage. Academy of Management Review, 23(4), 660-679. 
Gulati, R., \& Singh, H. (1998). The Architecture of Cooperation: Managing Coordination Costs and Appropriation Concerns in Strategic Alliances. Administrative Science Quarterly, 43(4), 781-814.

Gulati, R. (1998). Alliances and Networks. Strategic Management Journal, 19, 293-317.

Hatfield, L., Pearce, J., Sleeth, R., \& Pitts, M. (1998). Toward validation of partner goal achievement as a measure of joint venture performance. Journal of Managerial Issues, $10(3), 355-372$.

Heimeriks, K., Klijn, E., \& Reuer, J. (2009). Building Capabilities for Alliance Portfolios. Long Range Planning, 42, 96-114.

Holmberg, S., \& Cummings, J. (2009). Building Successful Strategic Alliances. Strategic Process and Analytical Tool for Selecting Partner Industries and Firms. Long Range Planning, 42, 164-193.

Hitt, M., Hoskisson, R., \& Ireland, D. (2007). Management of strategy. Concepts and Cases. Mason, $\mathrm{OH}$ : Thomson Higher Education.

Hoetker, G., \& Mellewigt, T. (2009). Choice and performance of governance mechanisms: matching alliance governance to asset type. Strategic Management Journal, 30, 10251044.

Hoffmann, W. (2005). How to Manage a Portfolio of Alliances. Long Range Planning, 38, 121143.

Hoffmann, W. (2007). Strategies for Managing a Portfolio of Alliances. Strategic Management Journal, 28, 827-856.

Kale, P., Singh, H., \& Perlmutter, H. (2000). Learning and protection of proprietary assets in strategic alliances: Building relational capital. Strategic Management Journal, 21, 3, 217-237.

Kale, P., Dyer, J., \& Singh, H. (2002). Alliance capability, stock market response, and longterm alliance success: the role of the alliance function. Strategic Management Journal, 23, 747-767.

Kandemir, D., Yaprak, A., \& Cavusgil, T. (2006). Alliance Orientation: Conceptualization, Measurement, and Impact on Market Performance. Journal of the Academy of Marketing Science, 34(3), 324-340.

Kauser, S., \& Shaw, V. (2004). The influence of behavioral and organisational characteristics on the success of international strategic alliances. International Marketing Review, 21(1), 17- 52.

Krishnan, R., Geyskens, I., \& Steenkamp, J-B. (2015). The effectiveness of contractual and trust-based governance in strategic alliances under behavioral and environmental uncertainty. Strategic Management Journal, 37(12), 2521-2542.

Lehene, C., \& Borza, A. (2017). An integrative framework of relational governance mechanism building in strategic alliances. Review of Economic Studies and Research Virgil Madgearu, 10(2), 95-131.

Lehene, C. (2018). Alliance Contracts Complexity and Firm's Performance. A Quantitative Investigation in Large and Medium Firms. International Journal of Economics, Business and Management Research, 3(2), 290-311.

Lehene, C. (2020). Strategii de colaborare între companii. Contribuții privind creșterea performanțelor relaționate cu productivitatea și inovarea. Cluj-Napoca: Presa Universitară Clujeană.

Luvison, D., \& de Man, A-P. (2015). Firm performance and alliance capability: the mediating role of culture. Management Decision, 53(7), 1581-1600.

Meier, M., Lütkeweitte, M., Mellewigt, T., \& Decker, C. (2015). How managers can build trust in strategic alliances: a meta-analysis on the central trust-building mechanisms. Journal of Business Economics, 1-29.

Moeller, K. (2010). Partner selection, partner behavior, and business network performance. An empirical study on German business networks. Journal of Accounting and Organizational Change, 6(1), 27-51. 
Nicolescu, O. \& Popa I. (2011). Strategia și managementul strategic. București: Editura Prouniversitaria.

O’Reilly, C. \& Tushman, M. (2013). Organizational Ambidexterity: Past, Present and Future. Academy of Management Perspectives (in press), 1-30.

Piața Financiară (2017, February 8). Top 1000 companii după cifra de afaceri pe 2015. Piața Financiară. Retrieved from: http://www.piatafinanciara.ro/top-1000-companiidupa-cifra-de afaceri-pe-2015/.

Popa, I. (2004). Ghid de realizare a strategiei. Bucuresti: Editura ASE.

Popa, M., Lungescu, D., \& Salanță, I. (2013). Management: Concepte, Tehnici, Abilități. ClujNapoca: Editura Presa Universitară Clujeană.

Sarkar, M.B., Echambadi, R., Cavusgil, T., \& Aulakh, P. (2001). The Influence of Complementarity, Compatibility, and Relationship Capital on Alliance Performance. Journal of the Academy of Marketing Science, 29(4), 358-373.

Stolwijk, C., den Hartigh, E., Vanhaverbeke, W., Ortt, J., \& van Beers, C. (2015). Cooperating with technologically dis(similar) alliance partners: the influence of the technology life cycle and the impact on innovative and market performance. Technology Analysis \& Strategic Management, 27(8), 925-945.

Taylor, A. (2005). An operations perspective on strategic alliance success factors: An exploratory study of alliance managers in the software industry. International Journal of Operations \& Production Management, 25(5), 469-490.

Tushman, M., \& O'Reilly, C. (1996). The ambidextrous organization: managing evolutionary and revolutionary change. California Management Review, 38, 1-23.

Vapola, T.J., Paukku, M., \& Gabrielsson, M. (2010). Portfolio management of strategic alliances: An international business perspective. International Business Review, 19, 247-260.

Vlăsceanu, M. (2003). Organizații și comportament organizațional. Iași: Polirom.

Wahyuni, S., Ghauri, P., \& Karsten, L. (2007). Managing International Strategic Alliance Relationships. Thunderbird International Business Review, 49(6), 671-687.

Wallenburg, CM. \& Schäffler, T. (2014). The Interplay of Relational Governance and Formal Control in Horizontal Alliances. Journal of Supply Chain Management, 50(2), 41-58.

\section{Appendix. Alliance monitorization and control items}

The score for the independent variable AMC was composed from summing the scores of nine items. The AMC was divided then in Structural Control Factors (SCF) and Control Process Factors (CPF). (Translated from Romanian.)

Structural Control Factors:

1. Our alliances have clear goals.

2. In our company there are employees responsible for overseeing our alliances.

3. We evaluate, systematically, at some periods of time, the added value of an alliance.

4. We evaluate, systematically, at some periods of time, if an alliance has to be stopped, prolonged or if there are required changes in formal or relational governance mechanism.

5. Our alliance managers constantly report about alliance progress and performances.

Control Process Factors:

1. We give and receive feedback and recommendations to/from our partners if activities in the alliance take place according to established goals.

2. We monitor if our partners in an alliance respect established procedure.

3. We give advice and recommendations to our partners when an alliance goes in a wrong direction.

4. In our alliances when partners behave opportunistically, if the case, we terminate the relationship. 